\title{
Entrepreneurial Leadership, Market Orientation, and Firm Performance
}

\author{
Clement Nangpiire, Paul Bangniyel \\ University for Development Studies (UDS), Tamale, Ghana
}

\begin{abstract}
This paper explores entrepreneurial leadership, market orientation, and firm performance. It sorts to ascertain through the literature whether entrepreneurial leadership has an influence on market orientation decision and firm performance. The review points to the fact that entrepreneurial leadership creates visionary scenarios which they used to assemble and mobilize a "supporting cast" of participants who become committed to the vision and the discovery of strategic value creation by influencing market orientation decision and thus enhancing firm performance. The study thus developed a process model as a result of the literature reviewed. The study concludes that, entrepreneurial leadership influences the market orientation decision of a firm with the help of the "supporting cast" and this helps the firm to increase its performance.
\end{abstract}

Keywords: entrepreneur, entrepreneurship, entrepreneurial leadership, market orientation, firm performance

\section{Introduction}

Entrepreneurship is a precursor to the economic development of the private sector in most developing countries. As such, countries that host a lot of genuine entrepreneurs have the opportunity to propel their growth through the hop of the economy which is the private sector. In most countries particularly the developing countries, the private sectoris are always seen as and touted as the engine of growth. The relevance of entrepreneurship to the development of countries cannot be overemphasized and particularly its importance to firm growth. Numerous studies in the past have established that there is a positive relationship amongst entrepreneurial leadership attributes and a variety of performance variables in the firm. Authors such as Gupta, MacMillan, and Surie (2004) and Wolff, Pescosolido, and Druskat (2002) have all in one way or the other illustrated this relationship between entrepreneurial leadership's attributes and the variety of performance indicators in business firms. The performance of a small firm for instance could be determined by the personality of its entrepreneur (Wood, 2002).

Since entrepreneurship and leadership are not one-dimensional perspectives, leadership is seen by González and Guillén (2002) as a multidimensional construct, which is made up of technical, psycho-emotive, and the ethical dimensions. In this way, it therefore implies that entrepreneurial leadership could also influence

Clement Nangpiire, Ph.D., lecturer, School of Business and Law (SBL), University for Development Studies (UDS), Wa Campus, Ghana.

Paul Bangniyel, Ph.D., lecturer, School of Business and Law (SBL), University for Development Studies (UDS), Tamale, Ghana.

Correspondence concerning this article should be addressed to Clement Nangpiire, School of Business and Law (SBL), University for Development Studies (UDS), P. O. Box, 520, Wa Campus-Ghana-West Africa. 
business performance when the right combination of strategies is employed. When the entrepreneur uses his qualities with the support of a serene macro-economic environment and with the right caliber of team, it can propel the firm to greater heights. It is not every person who has the ability to seize opportunities in the environment to be an entrepreneur. Some individuals have the gifts to access business opportunities whiles others are adamant to such opportunities. An entrepreneur therefore needs to have a kind of alertness to, and seizing of profit opportunities by taking innovative actions at the right time (Kirzner, 1973; Kolasa, Rubaszek, \& Taglioni, 2010). People who are able to get hold of these opportunities and take actions will therefore become entrepreneurs who set up businesses in countries and nurture them to grow. There are some factors that explain how these opportunities come about and why some people and certain organizations make use of the opportunities while others do not (Shane \& Venkataraman, 2000). As to how entrepreneurs come about, there is a consensus that apart from the personal characteristics of the entrepreneur, there are certain "external enablers": Davidsson (2015) influencing the amount, Estrin, Korosteleva, and Mickiewicz (2013) and the nature of entrepreneurial activity, Baumol (1990) due to the impact of these enablers on the disequilibrium economy that is the profit opportunities emerging and the entrepreneurs' abilities to seize them. Some of these enablers are visible to those who have the capacity and capability to seize these opportunities. These external enablers are natural disasters, technological innovations, financial and market characteristics as well as long-term, structural factors, such as the set of rules or institutions (Lofstrom, Bates, \& Parker, 2014; Parker, 2009). This paper thus intends to establish from the literature whether entrepreneurial leadership has an influence on market orientation decision and firm performance and develop a process model. It also looked at how moderating factors such as team work aids entrepreneurial leaders to take a decision to adopt a market orientation strategy and how it influences on the growth of a business. The next section of this paper reviews the relevant literature, proposes a process model, and makes some suggestions and conclusions based on the literature reviewed.

\section{Literature Review}

Entrepreneurial leadership is borne out of entrepreneurship and leadership (Rajsheree, David, \& $\mathrm{Mb}$, 2010). When an entrepreneur with the right qualities such as pro-activeness, innovativeness who takes risks and combines that with his leadership qualities such as technical, psycho-emotive, and ethical, it will give birth to entrepreneurial leadership which will have the required capacity to take a strategic orientation decision such as market orientation to enable the firm to perform (Seenivasan, 2014). It is the case that a relevant combination of the qualities of an entrepreneur and that of leadership may yield positive results. An entrepreneur needs to have a kind of alertness to and seizing of profit opportunities by taking innovative actions at the right time (Kirzner, 1973; Kolasa et al., 2010). How the combination of these key constructs could lead to positive performance in a firm is clearly demonstrated in this section.

\section{The Concept of Leadership}

There is no doubt that there has been quite a number of authors who delved deeply into the literature to unearth that there is a positive relationship amongst leadership traits and a range of performance variables in their scholarly studies. For instance, Gupta, MacMillan, and Surie (2004) and Wolff, Pescosolido, and Druskat (2002) have all in different ways demonstrated that there is this relationship. As suggested by Wood (2002), the performance of small firms could be determined by the personality of its entrepreneur at the center of affairs. 
As such entrepreneurship and leadership are seen as multi-dimensional perspectives. In their study, González and Guillén (2002) have seen leadership as a multidimensional construct which comprises of technical, psycho-emotive, and the ethical dimensions. González and Guillén (2002) argue that, the technical dimension of leadership measures the effectiveness of the leader's impact on those who follow him lher. With regards to the psycho-emotive dimension of leadership they stressed that it refers to the individual personal characteristics and the amount of social skills the leader has that can establish a conducive climate for the followers to support his/her initiated policies.

In his contribution, Ireland, Hitt, and Sirmon (2003) referred to these dimension as "Social Capital". They further divided it into "internal social capital" and "external social capital". For them the internal social capital is the inter- and intra-relationships amongst the individuals of the same firm and the external social capital has to do with the relationships that exist among the individuals and the members of other organizations, when well harness could lead to value creation. From this point of view, they added that the difference between owner-managers and their employees is regarded as internal social capital whiles the relationship between the owner-managers and individuals lorganizations which are external to the venture is seen as external social capital (Ireland et al., 2003). González and Guillén (2002) say the psycho-emotive dimension of leadership has to do with the attractiveness of the leader's social life and influence on the people who are his ther followers. With regard to the ethical dimension of leadership, they added that it involves how right or good the intensions of a leader are and how to morally correct a leader behaves in the eyes of the followers.

Engelbrecht, Aswegen, and Theron (2005) also highlighted on the importance of positive relationships between transformational leaders as well as ethical climate and ethical values in an institution. They are of the view that in institutions where the leaders are seen to behave ethically and thus make ethical decisions, there should be an atmosphere of ethical values. In that regard, high standards of business ethics can only be realized if there is an endless commitment and an enforcement and modeling of leadership in the institution (Banerji \& Krishnan, 2000). It is said that ethical business values such as honesty, fairness, mutual respect, kindness, and even just by showing goodwill to others would benefits leaders in their effort to build trust and develop good rapport with their followers (London, 1999). One must therefore have a blend of leadership with entrepreneurship in trying to exhibit ethical values in our world of business today.

\section{Entrepreneurship}

In the view of Covin and Slevin (1989), entrepreneurial orientation is made up of pro-activeness, risk-taking, and innovativeness that are meant to enhance the business performance. On the other hand Morris (1997) sees entrepreneurship as a kind of a value adding process in a business or an enterprise, whiles Kaufmann and Dant (1998) explain entrepreneurship to be a mixture of behavioral characteristics which indicates the way they operate and the sort of activities that they engaged themselves in. These diverse but researched views of various scholars about the definition of entrepreneurship give us the indication that entrepreneurship has several perspectives. It has a blend of wide-ranging philosophies that together explains the phenomenon (Johannes \& Zyl, 2007).

Scholars such as Antoncic and Hisrich (2004) and Goosen, Coning, and Smit (2002) in their various researches established that there is a positive relationship between entrepreneurship and organizational wealth creation, profitability, and growth of a firm. In the same vein, elements of entrepreneurship such as: innovation, innovation orientation, pro-activeness, entrepreneurial orientation, entrepreneurial proclivity and creativity, 
Johannes and Zyl (2007) have also been linked positively to various measures of organizational performance in their various studies. Therefore, the entire integration of these dimensions of entrepreneurship of Covin and Slevin (1989) and that of leadership of González and Guillén (2002) create a complex entrepreneurial leadership construct (Johannes \& Zyl, 2007). This therefore implies that the entrepreneurial leadership construct would then make up of: pro-activeness, risk taking propensity, innovativeness, psycho-emotive, technical and ethical dimensions (Johannes \& Zyl, 2007).

Entrepreneurship has longed been noticed as a central driver of productivity growth, innovation, employment, and competitiveness (Ács, Szerb, Ortega-Argilés, Aidis, \& Coduras, 2015). It is one of the key aspects to economic dynamism and has clearly influenced the economic growth of countries and regions in the world (Organisation for Economic Co-operation and Development, 2008). Entrepreneurship and the formation of new businesses are very important elements in the regional economic growth in that, they have an influence on the composition of the regional industrial base which is a very important predictor of the growth and performance differences existing between regions (Audretsch \& Feldman, 2004). As a result, the contribution of entrepreneurship to regional growth differs from region to region, but this is even after taking into account differences in the sectorial composition of economies (Rajsheree et al., 2010). They added that it is clear that existing evidence highlights a very large difference in entry rates but also in the post-entry performance of firms that are young between regions.

It is clear that innovation appears as an inherent characteristic of entrepreneurship since innovation and entrepreneurship need to go hand in hand, in such a way that the multiple dimensions of the company's relationship with the entire environment (institutional development, resource allocation, and commercialization) will enable innovation to develop (Woolley \& Rottner, 2008). The actual concept of entrepreneurship and the need for the entrepreneurs to protect innovation in the company's framework, is what makes entrepreneurship and innovation necessarily converge in the world of economics and also management (Jean-Sahut \& Peris-Ortiz, 2014).

With regards to the relationships that exist between small businesses and entrepreneurship and innovation, new combinations of factors often occur with the start-ups of new businesses thereby creating a strong association between small enterprises and entrepreneurship, which constitutes one of the largest fields of entrepreneurial activity (Blackburn \& Kovalainen, 2009). However, this does not stop entrepreneurial orientation from extending its tentacles to activities that exceed the field of small businesses which can be profitable (Shane, 2012). However, the conditions in small enterprises for innovations that do not require size but need close cooperation and involvement from their members may be very unique and cannot be reproduced in large companies (Jean-Sahut \& Peris-Ortiz, 2014). Therefore, small businesses entrepreneurship and innovation, deliberated together, will have a significant position in the world of business.

\section{Entrepreneurial Leadership}

Just like most concepts in the academia, the concept of entrepreneurial leadership has also seen multiple explanations and definitions since its inception. It refers to the combined characteristics of the terms entrepreneurship and leadership concepts. For instance, Gupta et al. (2004) describe entrepreneurial leadership as the kind of leadership that creates visionary scenarios which are used to assemble and mobilize a "supporting cast" of participants who become committed by the vision to the discovery and exploitation of strategic value creation in the firm. Lerner and Haber (2000) call them the human capital approach in their research on small 
business ventures in Israeli tourism. They came out with some qualities and skills such as managerial and personal characteristics, such as internal locus of control, achievement orientation and autonomy which are critical for effective performance of a tourism entrepreneur and small venture performance. For small and micro firms these characteristics of the owner-manager are very essential for the venture to perform effectively.

Entrepreneurial leadership is also seen by Swiercz and Lydon (2002) as those individuals who initiate, develop, and mostly manage entrepreneurial organizations. Ireland et al. (2003) agree with authors such as Covin and Slevin (2002) and Ireland and Hitt (1999) who say that entrepreneurial leadership is the ability of the leader to influence others to manage the organizations' resources strategically in order to emphasize both opportunity-seeking and advantage-seeking behaviors. These views of entrepreneurship bring to light the fact that entrepreneurial leaders need to have the capacity to explore the in-and-out of their environments and identify some useful opportunities that could be exploited for their benefits and at the same time entice others to enthusiastically participate in this process towards value creation for the society (Johannes \& Zyl, 2007). As such entrepreneurial leaders ought to also practice market orientation in their businesses in order to increase their competitiveness and enhance their performance.

Ireland et al. (2003) in their paper also roped in the concept of strategic entrepreneurship which they say highlights the complementarities within strategy and entrepreneurship. As in Hagen, Mundia, Anton, and Bernhard (2012, p. 281) the concept "strategic" can be explained as "that which relates to the long-term prospects of the company and has a critical influence on its success or failure". Additionally, the term "entrepreneurship" has also found its definition in the Schumpeterian notion of the creation of new products, processes, markets, and organizational forms (Schumpeter, 1934).

A lot of scholars have highlighted the need for entrepreneurial action with a strategic perspective to enable a firm to survive competition. Whether strategic entrepreneurship is undertaken by new ventures or already established organizations, it entails a dual focus on trying to create change, exploiting or appropriating the value through the change created. It is a fact that wealth is normally created when firms try to combine effective opportunity-seeking behavior which is (entrepreneurship) with effective advantage seeking behavior that is strategic management (Ireland et al., 2003).

It is important to note that strategic entrepreneurship surpasses levels of analysis and has encompassed a number of actions which are under-taken by individuals, teams, and firms, in an intra-or inter-organizational perspective (Rajsheree et al., 2010). It is not also the domain of new and young or small firms alone. It also applies to well established firms since much innovation and entrepreneurship can be undertaken by established firms who are seeking to strategically renew themselves through entrepreneurial activity (Hagen et al., 2012).

Strategic entrepreneurship also applies to the actions taken by founders of most new ventures (Bhide, 1994) and other managers of organizations already in existence (Covin \& Slevin, 2002). Collectively, some of these actions come to explain the birth, growth, and demise of organizations, industries, regions, and economies at large. It is however not surprising that, Schumpeter (1934) discussed the competitive consequences of entrepreneurial action at the individual level, firm, industry, and economy levels when he sorts to elaborate on the process of creative destruction in firms.

Hitt, Haynes, and Serpa (2010) and Ireland and Hitt (1999) in their various articles also portrayed the capabilities that are needed in the firm for effective strategic leadership especially in the new competitive environment anticipated for the changing 21 st century. Their contention is that, in this 21 st century, effective strategic leaders had no choice but to: develop and communicate a vision, build dynamic core competencies, 
emphasize and effectively use human capital, invest in the development of new technologies, engage in valuable strategies, build and maintain an effective organizational culture, develop and implement balanced controls and engage in ethical practices in their firms. An effective entrepreneurial leader can function in collaboration with other stake holders to take the right orientation which will help to move the firm in the right direction in order to enhance firm performance (Hitt et al., 2010; Ireland \& Hitt, 1999).

It is generally said that entrepreneurship triumphs during stable economic period when the entire environment is serene. Financial stability can foster entrepreneurship activities in a country in two main ways: In the first instance, financial stability provides fertile ground for entrepreneurship as economic transactions are largely governed by "conventional" behavior (Choi, 1999). In the view of Choi, established firms have adapted to routines and neglect emerging profit opportunities. He argued that alert agents can discover these opportunities because, given the stable environment, they can focus on a rather narrow part of the economic system when engaging in a new venture while basically ignoring the rest of the economy (Harper, 2003).

Secondly, financial markets which are important in entrepreneurial development normally work properly during periods of economic stability which provides entrepreneurs with the best needed capital to actually seize the existing opportunities. As a result of this, it is said that stability is a precondition for the effective operation of those basic forces of enterprise, ingenuity, invention, hard work, and thrift that are the real and true springs of economic growth in countries (Friedman, 1968).

Some authors do argue that financial crises discourage entrepreneurship because it creates a level of uncertainty that exacerbates the entrepreneur's job of discovering business opportunities. It is truism that some entrepreneurs will usually hesitate to take advantage of opportunities during financial crisis because of the debilitating effect it can bring. For instance, Schumpeter (1934) views crisis times as periods where the process of "creative destruction" continues, but ceases to be smooth and turns disruptive since it represents the response of a large number of entrepreneurs to disequilibria emerging from a period of stability (Choi, 2012; Parker, 2012). Nofsinger and Wang (2011) in order to sooth entrepreneurs indicated that it is true that crisis times lead to a credit crunch in the formal financial sector but this might be of less relevance for small and young businesses since they commonly rely on informal sources of finding. It is evident from the literature that entrepreneurship does and should flourish in periods of stability.

For the past years, entrepreneurship research has been devoted to defining entrepreneurship or entrepreneurial activity and applying some definitions in empirical research with the use of the following three approaches: The first approach according to the authors measures the entrepreneurial attitude of firms via special research questionnaires (Douglas, 2013). The resulting indicator is then used as an explanatory variable of firm performance (Anderson \& Eshima, 2013; Soininen, Martikainen, Puumalainen, \& Kyläheiko, 2012) including when firms face a change in the external environment. The second approach measures entrepreneurship by assessing the level of innovation (for instance, product, or process innovation) within firms. A higher level of innovation is associated with a more entrepreneurial mindset. The third approach attaches the attribute "entrepreneurial" to specific, readily observable firm characteristics. "Small" and "young" are the preferred characteristics because large and mature firms are the prime candidates for adopting "conventional" behavior as stated by Choi (1999) that sometime leads to a "stationary state" (Choi, 2012) in times of stability and as such they lack alertness and the ability to respond quickly to emerging profit opportunities (Anderson \& Eshima, 2013; Bamford, Dean, \& Douglas, 2004). 


\section{Market Orientation}

Market orientation has been researched by many scholars. For instance, Foley and Fahy (2004) and Homburg, Krohmer, and Workman Jr. (2004) among other scholars have researched and found that there is a positive relationship between market orientation and a firm's performance. It can however be said that the seminal work of Kohli and Jaworski (1990) and Narver and Slater (1990) were the papers which stirred successive researchers on relationship between market orientation and their influence on business or firm performance. Market orientation is seen as the generation of marketing intelligence, the dissemination of intelligence, and the responsiveness to the acquired intelligence (Kohli \& Jaworski, 1990). In their study, Narver and Slater (1990) came out with the proposition of the behavioral components which includes customer orientation, a competitor orientation and inter-functional coordination, as portion of market orientation. Furthermore, the four antecedent features such as the top management, the organizational systems, interdepartmental dynamics, and a reward system orientation that could subsequently influence market orientation were also popularized by Pulendran, Speed, and Widing (2000).

In the light of the above, Harris and Ogbonna (2001) emphasized that leadership style is also a critical antecedent of market orientation. They found that a participative and supportive leadership style facilitates the development of market orientation in the business. It is clear that superior customer value is a mediator that can connect market orientation to performance as indicated by Guo (2002). Though market orientation looks at customer orientation, a competitor orientation and inter-functional coordination (Narver \& Slater, 1990), relationship marketing from the point of view of Sin, Tse, Yau, Chow, and Lee (2002) focuses on the individual buyer and seller relationships and that both parties in each individual buyer and seller relationship benefit at the end. This means that when market orientation and relationship marketing orientation which are both strategic orientations are used at the same time, superior customer value (satisfaction) would be created which would go a long way to enhance organizational/firm performance. It is therefore incumbent on firms to reach out to their customers to satisfy them since customer satisfaction is key to business survival particularly in today's competitive business environment.

\section{Discussions}

Based on the several literatures reviewed, the paper developed this process model as an illustration of how entrepreneurial leadership can combine instruments to facilitate performance.

In this case, the relevant combination of the qualities of an entrepreneur and that of leadership would yield positive results for the business. The desire of entrepreneurial leaders to entice others to enthusiastically participate in this process towards value creation for the society as suggested by Johannes and Zyl (2007) is what Gupta et al. (2004) refered to as the "supporting cast" when they (Gupta et al., 2004) describes entrepreneurial leadership as the kind of leadership that creates visionary scenarios which are used to assemble and mobilize a "supporting cast" of participants who become committed by the vision, the discovery and manipulation of strategic value creation in the firm. These "supporting cast" or team of participants help the entrepreneur in the daily implementation of the vision and the discovery and exploration of various strategies to further create value for their consumers in order to stay in business by increasing performance.

In this process, the team of participants and the entrepreneurial leader could adopt a market orientation decision. Market orientation is therefore seen as the generation of marketing intelligence, the dissemination of intelligence, and the responsiveness to the acquired intelligence (Kohli \& Jaworski, 1990). Narver and Slater 
(1990) in their study came out with the proposition of the behavioral components of market orientation which includes customer orientation, a competitor orientation, and inter-functional coordination, as ingredients of market orientation. Additionally, the four antecedent features such as the top management, the organizational systems, interdepartmental dynamics, and a reward system orientation that could subsequently influence market orientation were however popularized by Pulendran, Speed, and Widing (2000). The adoption of market orientation brings the firm closer to it its customers. It also positions the firm in a way that enables it to closely watch or monitor the activities of their competitors. Market orientation strategy results in members of the firm working together in their efforts to deliver value to their customers for the purpose of enhancing performance.

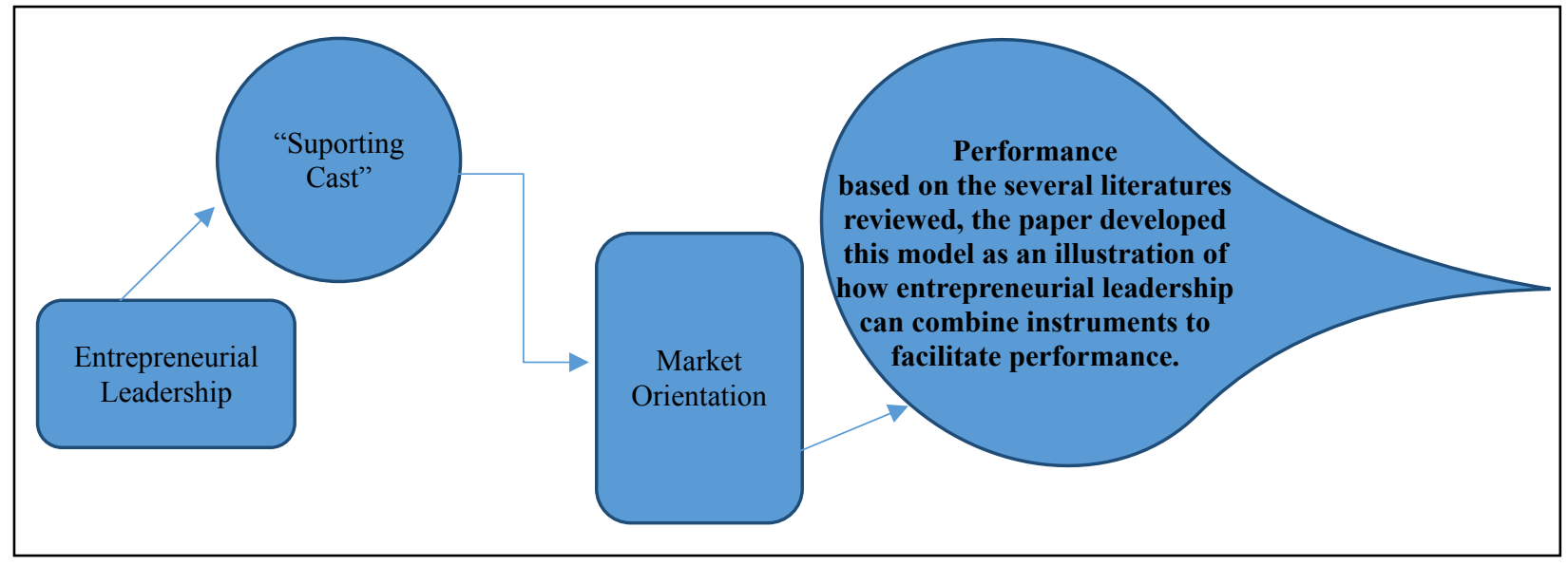

Figure 1. Process model.

The above explanations of market orientation led Harris and Ogbonna (2001) to insist that leadership style is also a critical precursor of market orientation. It is clear that participation and support to the entrepreneurial leaders' flair facilitate the development of superior customer value and market orientation in the firm. Therefore, superior customer value which could be occasioned by market orientation is a mediator that can connect market orientation to performance (Guo, 2002). As such, superior customer value which can be termed as a competitive advantage for the firm can also lead to increase in business performance.

It is truism that the terms competitive advantage and performance are very much used interchangeably, but they are acknowledged to be conceptually different (Powell, 2001). Whilst competitive advantage is seen or conceptualized as the implementation or operation of a strategy that is not currently implemented anywhere by other firms that will facilitate the reduction of costs, the exploitation of market opportunities and/or the neutralization of competitive threats Barney (1991), performance on the other hand is generally conceptualized as the rents a firm amasses because the firm has implemented certain strategies which its competitors has not implemented (Rumelt, Schendel, \& Teece, 1994). As a result, the firm overpowers or outwits its competitors in the market and become dominant in the market which helps the firm to increase its sales and thus enhance its performance.

Bridoux (2004) says that a firm which has attained a competitive advantage has kind of created more economic value (the difference between the perceived benefits of a resource-capability combination and the economic cost to exploit them) than its competitors in the market. They added that economic value is generally created when manufacturing products and/or services with greater benefits at the same cost compared to competitors in same market that is differentiation-based competitive advantage or the same benefits at lower 
cost as compared to competitors which is termed as efficiency-based competitive advantage. This is because superior benefits tend to enhance customer loyalty and perceived quality (Akintoye, 2006).

As such, a firm led by an entrepreneurial leader(s) can exploit its resource-capability combinations to effectively attain a differentiation-based competitive advantage which will enable it to improve its performance compared to competitors by selling more units at the same margin (parity price) or by selling the same number of units at a greater margin that is premium price as suggested by Rajiv, Donald, and Ming-Jer (2006). In a similar vein, if the said firm has a superior cost structure which enables greater pricing flexibility as well as the ability to increase available surplus (Porter \& Millar, 1985), then that firm can surely exploit its resource-capability combinations to effectively attain an efficiency-based competitive advantage which will go a long way to enable it to improve its performance as compared to competitors by selling more units at the same margin which is low price or by selling the same number of units at a greater margin which is parity price. In any of these cases, it is clear and logical to say that a firm that is able to attain such a competitive advantage, be it as a result of greater benefits at the same cost or the same benefits at lower cost, will be heading towards improving its performance in ways that its competitors cannot match in the market (Rajiv et al., 2006). Therefore, the ability of the entrepreneurial leader, together with his committed team (supporting cast) has the capability to take cogent decisions among which is the decision of market orientation to enable them outwit their competitors and to facilitate or enhance firm performance.

\section{Conclusion}

The study set off to ascertain from the literature review whether entrepreneurial leadership has an influence on market orientation decision and firm performance. It examined entrepreneurship and how the qualities of entrepreneurs such as pro-activeness, innovativeness and risks taking, blending with technical, psycho-emotive and ethical coupled with the decision to adopt a market orientation strategy could have an influence on the performance of a business. The literature reviewed points to the fact that entrepreneurial leadership has an influence on market orientation decision and firm performance. The study therefore developed a process model as its contribution to literature.

Therefore, even though a firm's performance can be influenced by a lot of exogenous effects, the competitive advantages a firm attains are surely an important antecedent toward this end (Rajiv et al., 2006) and this can be facilitated by an entrepreneurial leadership with the right strategic combinations. As a result, the real performance of firms that are able to achieve superior customer value through market orientation by putting in place the required strategy, will surely be greater than the performance of those other firms that are not able to achieve superior customer value through market orientation due to the failure of the entrepreneurial leaders of such businesses to adopt a workable strategy.

In a nutshell, when a firm with an entrepreneurial leadership is able to develop and shares a vision with his "supporting cast" or team of participants, they will help the entrepreneur in the daily implementation of the vision and the discovery and exploration of various strategies to further create value for their consumers. In this process, the team of participants and the entrepreneurial leader would adopt a market orientation decision which is a precursor for the creation of superior customer value which will go a long way to enhance its performance in the market. Therefore, entrepreneurial leadership can influence the market orientation decision of a firm with the help of the "supporting cast" and with the provision of superior value which leads the firm to increase its performance. 


\section{References}

Ács, Z. J., Szerb, L., Ortega-Argilés, R., Aidis., R., \& Coduras, A. (2015). The regional application of the global entrepreneurship and development index (GEDI): The case of Spain. Regional Studies, 49(12), 1977-1994.

Akintoye, I. R. (2006). Enhancing the performance of the informal sector for the economic development of Nigeria: A case study of Lagos State. International Journal of Social Sciences, 5(1), 100-112.

Anderson, B. S., \& Eshima, Y. (2013). The influence of firm age and intangible resources on the relationship between entrepreneurial orientation and firm growth among Japanese SMEs. J. Bus. Ventur., 28(3), 413-429.

Antoncic, B., \& Hisrich, R. D. (2004). Corporate entrepreneurship contingencies and organizational wealth creation. Journal of Management Development, 23(6), 518-550.

Audretsch, D., \& Feldman, M. (2004). Knowledge spillovers and the geography of innovation. Handbook of Regional and Urban Economics, 4, 2713-2739. Amsterdam: Elsevier.

Bamford, C. E., Dean, T. J., \& Douglas, T. J. (2004). The temporal nature of growth determinants in new bank foundings: Implications for new venture research design. Journal of Business Venture Business Venture, 19(6), 899-919.

Banerji, P., \& Krishnan, V. R. (2000). Ethical preferences of transformational leaders: An empirical investigation. Leadership \& Organization Development Journal, 21(8), 405-413.

Barney, J. (1991). Firm resources and sustained competitive advantage. Journal of Management, 17(1), 99-120. Retrieved from http://doi.org/10.1177/014920639101700108

Baumol, W. J. (1990). Entrepreneurship: Productive, unproductive, and destructive. Journal of Political Economy, 98(5), 893-921.

Bhide, A. (1994). How entrepreneurs craft strategies that work. Harvard Business Review, 72(2), 150-161.

Blackburn, R., \& Kovalainen, A. (2009). Researching small firms and entrepreneurship: Past, present and future. International Journal of Management Reviews, 11(2), 127-148.

Bridoux, F. (2004). A resource-based approach to performance and competition: an overview of the connections between resources and competition. Luvain, Belgium Institut et de Gestion, Universite Catholique de Louvain. Retrieved from http://www.uclouvain.be/cps/ucl/doc/iag/documents/WP_110_Bridoux.pdf

Choi, Y. B. (1999). Conventions and economic change: A contribution toward a theory of political economy. Constit. Polit. Econ., $10,245-264$.

Choi, Y. B. (2012). Institutions for economic prosperity—an entrepreneurial perspective. In Y. B. Choi (Ed.), Institutional economics and national competitiveness (pp. 63-83). New York: Routledge.

Covin, J. G., \& Slevin, D. P. (1989). Strategic management of small firms in hostile and benign environments. Strategic Management Journal, 10(1), 75-87.

Covin, J. G., \& Slevin, D. P. (2002). The entrepreneurial imperatives of strategic leadership. In M. A. Hitt, R. D. Ireland, S. M. Camp, and D. L. Sexton (Eds.), Strategic entrepreneurship: Creating a new mindset (pp. 307-327). Oxford: Blackwell Publishers.

Davidsson, P. (2015). Entrepreneurial opportunities and the entrepreneurship nexus: A re-conceptualization. Journal of Business Venture, 30(5), 674-695.

Douglas, E. J. (2013). Reconstructing entrepreneurial intentions to identify predisposition for growth. Journal of Business Venture, 28(5), 633-651.

Engelbrecht, A. S., van Aswegen, A. S., \& Theron, C. C. (2005). The effect of ethical values on transformational leadership and ethical climate in organizations. South African Journal of Business Management, 36(2), 19-26.

Estrin, S., Korosteleva, J., \& Mickiewicz, T. (2013). Which institutions encourage entrepreneurial growth aspirations? Journal of Business Venture, 28(4), 564-580.

Foley, A., \& Fahy, J. (2004). Towards a further understanding of the development of market orientation in the firm: A conceptual framework based on the market-sensing capability. Journal of Strategic Marketing, 12(4), 219-230.

Friedman, M. (1968). The role of monetary policy. Am. Econ. Rev., 58(1), 1-17.

González, T. F., \& Guillén, M. (2002). Leadership ethical dimension: A requirement in TQM implementation. The TQM Magazine, 14(3), 150-164.

Goosen, C. J., de Coning, T. J., \& Smit, E. v. d. M. (2002). Corporate entrepreneurship and financial performance: The role of management. South African Journal of Business Management, 33(4), 21-27.

Guo, C. (2002). Market orientation and business performance. A framework for service organizations. European Journal of Marketing, 36(9/10), 1154-1163. 
Gupta, V., MacMillan, I. C., \& Surie, G. (2004). Entrepreneurial leadership: Developing and measuring a cross-cultural construct. Journal of Business Venturing, 19, 241-260.

Hagen, W., Mundia, K., Anton, E., \& Bernhard, T. (2012). Strategic renewal and the change of capabilities in utility firms. European Business Review, 24(5), 444-464.

Harper, D. A. (2003). Foundations of entrepreneurship and economic development. London: Routledge.

Harris, L. C., \& Ogbonna, E. (2001). Leadership style and market orientation: An empirical study. European Journal of Marketing, 35(5/6), 744-764.

Hitt, M. A., Haynes, K. T., \& Serpa, R. (2010). Strategic leadership for the 21st century. Business Horizons, 53(5), 437-444. Retrieved from http://doi.org/10.1016/j.bushor.2010.05.004

Homburg, C., Krohmer, H., \& Workman Jr., J. P. (2004). A strategy implementation perspective of market orientation. Journal of Business Research, 57, 1331-1340.

Ireland, R. D., \& Hitt, M. (1999). Achieving and maintaining strategic competitiveness in the 21st century: The role of strategic leadership. Academy of Management Executive, 13(1), 43-57.

Ireland, R. D., Hitt, M. A., \& Sirmon, D. G. (2003). A model of strategic entrepreneurship: The construct and its dimensions. Journal of Management, 29(6), 963-989.

Jean-Sahut, M., \& Peris-Ortiz, M. (2014). Small business, innovation, and entrepreneurship. Small Bus Econ, 42, 663-668.

Johannes, H., \& Zyl, C. Van. (2007). Exploring a conceptual model, based on the combined effect of entrepreneurial leadership, market orientation and relationship marketing orientation on South Africa's small tourism ... performance. Journal of Business Management, 38(2), 16-24.

Kaufmann, P. J., \& Dant, R. P. (1998). Franchising and the domain of entrepreneurship research. Journal of Business Venturing, 14, 5-16.

Kirzner, I. M. (1973). Competition and entrepreneurship. Chicago and London: The University of Chicago Press.

Kohli, A., \& Jaworski, B. (1990). Market orientation: The construct, research propositions and managerial implications. Journal of Marketing, 54, 1-18.

Kolasa, M., Rubaszek, M., \& Taglioni, D. (2010). Firms in the great global recession: The role of foreign ownership and financial dependence. Emerg. Mark. Rev., 11, 341-357.

Lerner, M., \& Haber, S. (2000). Performance factors of small tourism ventures: The interface of tourism, entrepreneurship and the environment. Journal of Business Venturing, 16, 77-100.

Lofstrom, M., Bates, T., \& Parker, S. C. (2014). Why are some people more likely to become small-business owners than others: Entrepreneurship entry and industry-specific barriers. Journal of Business Venture, 29(2), 232-251.

London, M. (1999). Principled leadership and business diplomacy. Journal of Management Development, 18(2), 170-192.

Morris, M. H. (1997). Entrepreneurial intensity: Sustainable advantage for individuals, organizations and societies. Westport: Quorum Books.

Narver, J. C., \& Slater, S. F. (1990). The effect of a market orientation on business profitability. Journal of Marketing, 54(October), 20-35. Retrieved from http://doi.org/10.2307/1251757

Nofsinger, J. R., \& Wang, W. (2011). Determinants of start-up firm external financing worldwide. Journal of Banking and Finance, 35(9), 2282-2294.

Organisation for Economic Co-operation and Development. (2008). Handbook on constructing composite indicators-Methodology and user guide. Retrieved from http://composite-indicators.jrc.ec.europa.eu/Handook.htm

Parker, C. (2009). The economics of entrepreneurship. Cambridge: Cambridge University Press.

Parker, C. (2012). Theories of entrepreneurship, innovation and the business cycle. J. Econ. Surv., 26(3), 377-394.

Porter, M. E., \& Millar., V. A. (1985). How information gives you competitive advantage. Harvard Business Review, 63(4), $149-160$.

Powell, T. C. (2001). Competitive advantage: Logical and philosophical considerations. Strategic Management Journal, 22(9), 875-888. Retrieved from http://doi.org/10.1002/smj.173

Pulendran, S., Speed, R., \& Widing II, R. E. (2000). The antecedents and consequences of market orientation in Australia. Australian Journal of Management, 25(2), 119-143.

Rajiv, N., Donald, H., \& Ming-Jer, C. (2006). What is strategic mangement, really? Inductive derivation of a consensus definition of the field. Strategic Management Journal, 28(June 2006), 935-955. Retrieved from http://doi.org/10.1002/smj

Rajsheree, A., David, A., \& Mb, S. (2010). Knowledge spillovers and straegic entrepreneurship. Strategic Entrepreneurship Journal, 4, 271-283. Retrieved from http://doi.org/10.1002/sej 
Rumelt, R. P., Schendel., D. E., \& Teece., D. J. (1994). Fundamental issues in strategy: A research agenda. Brighton, Massachusetts: Harvard Business School Press.

Schumpeter, J. (1934). The theory of economic development: An inquiry into profits, capital, credit, interest, and the business cycle. Cambridge: Harvard University Press.

Seenivasan, R. (2014). Global research on women's entrepreneurship: An overview. Journal of Small Business and Entrepreneurship Development, 2(2), 121-140.

Shane, S. (2012). Reflections on the 2010 AMR decade award: Delivering on the promise of entrepreneurship as a field of research. Academy of Management Review, 37(1), 10-20.

Shane, S., \& Venkataraman, S. (2000). The promise of entrepreneurship as a field of research. Acad. Manag. Rev., 25(1), 217-226.

Sin, L. Y. M., Tse, A. C. B., Yau, O. H. M., Chow, R. P. M., \& Lee, J. S. (2002). Market orientation, relationship marketing orientation, and business performance: The moderating effects of economic ideology and industry type. Journal of International Marketing, 13(1), 36-57.

Soininen, J., Martikainen, M., Puumalainen, K., \& Kyläheiko, K. (2012). Entrepreneurial orientation: Growth and profitability of Finnish small- and medium-sized enterprises. Int. J. Prod. Econ., 140, 614-621.

Swiercz, P. M., \& Lydon, S. R. (2002). Entrepreneurial leadership in high-tech firms: A field study. Leadership and Organizational Development Journal, 23(7), 380-389.

Wolff, S. B., Pescosolido, A. T., \& Druskat, V. U. (2002). Emotional intelligence as the basis of leadership emergence in self-managing teams. The Leadership Quarterly, 13, 505-522.

Wood, E. H. (2002). An analysis of the predictors of business performance in small tourism and hospitality firms. International Journal of Entrepreneurship and Innovation, 3(3), 201-210.

Woolley, J. L., \& Rottner, R. M. (2008). Innovation policy and nanotechnology entrepreneurship. Entrepreneurship Theory and Practice, 32(5), 791-811. 